\title{
EDITORIAL
}

\section{Cell division tracking and expansion of hematopoietic long-term repopulating cells}

\author{
RAJ Oostendorp ${ }^{1,2,3}$, J Audet ${ }^{1}$, C Miller ${ }^{1}$ and CJ Eaves ${ }^{1}$ \\ ${ }^{1}$ Terry Fox Laboratory, British Columbia Cancer Agency, and University of British Columbia, Vancouver, BC, Canada; and ${ }^{2}$ GSF-Research \\ Center For Environment and Health, Munich, Germany
}

\begin{abstract}
The combined use of rigorous assays for quantitating transplantable stem cell numbers and precise cell labeling and tracking procedures have provided definitive evidence that stem cell self-renewal divisions can occur in vitro in the absence of stromal feeder layers. These findings set the stage for defining conditions that may alter the ability of these cells to maintain their primitive status when mitogenically activated.

Keywords: stem cells, self renewal, in vitro expansion
\end{abstract}

Clinical treatments involving the use of myeloablative regimens are dependent on the availability of a graft containing a sufficient number of hematopoietic stem cells to ensure permanent reconstitution of the entire hematopoietic system. In recent years, much interest has arisen in the potential of previously unexplored sources of hematopoietic stem cells which could benefit from, or require, being exposed to conditions that induce their proliferation and expansion ex vivo prior to being transplanted. Over the last few years, many studies have described cytokine combinations that support the production in vitro of large numbers of murine and human myeloid progenitors detectable as colony-forming cells (CFC) in semi-solid cultures. However, it is also now widely appreciated that very few, if any, of these cells have long-term in vivo engrafting potential. Moreover, a unique phenotype that can be functionally associated with this latter activity has not yet been identified. Thus, progress in addressing whether and how the expansion of hematopoietic stem cells can be achieved in vitro has been limited to studies that have used quantitative methods to analyze changes in the number of cells with long-term multi-lineage repopulating activity before and after culture (eg using the competitive repopulating unit, or CRU, assay ${ }^{1}$ ).

Because primary marrow stromal cell layers have been known for a long time to be capable of stimulating the proliferation and differentiation of very primitive hematopoietic cells, ${ }^{2-4}$ a number of investigators have sought to determine whether stem cell self-renewal divisions can also occur in stromal cell-containing cultures. As summarized in Table 1, simple measurements of the total numbers of in vivo repopulating cells (CRU) present after various periods of time have shown that there is a rapid decline in this population within a few weeks in cultures containing feeders of primary marrow cells. ${ }^{5-8}$ Nevertheless, clonal analysis ${ }^{9}$ and retroviral marking ${ }^{5}$ strategies have both demonstrated that this net decline occurs in the face of a significant expansion of a small proportion of the input CRU. Somewhat better overall results have since been obtained by groups using various cell lines, such as the S17 line, CFC034, 2012, AFT024, ${ }^{10,11}$ AGMS3 $^{12}$ and DAS104-4 ${ }^{13}$ cells as feeders. Recent studies have suggested

Correspondence: CJ Eaves, Terry Fox Laboratory, 601 West 10th Avenue, Vancouver, BC, V5Z 1L3, Canada; Fax: 16048770712 ${ }^{3}$ Current address: Department of Cell Biology and Genetics, Erasmus University, Rotterdam, The Netherlands

Received 17 December 1998; accepted 25 January 1999
Table 1 Stem cell numbers in cultures containing stroma

\begin{tabular}{lclr}
\hline Stroma & $\begin{array}{c}\text { Days of } \\
\text { culture }\end{array}$ & $\begin{array}{c}\text { Effect on stem cell numbers } \\
\text { (relative to input) }\end{array}$ & Ref. \\
\hline S17 & 7 & Decrease & 7 \\
DAS104-4 & 7 & Maintenance & 13 \\
S17 & 10 & Decrease & 21 \\
S17 & 14 & Decrease & 16 \\
S17 (+LIF) & 14 & Maintenance & 16 \\
S17 & 21 & Maintenance & 10 \\
2012 & 21 & Maintenance & 10 \\
CFC0342 & 21 & Maintenance & 10 \\
NMF & 28 & Decrease & 5 \\
NMF & 28 & Decrease & 6 \\
NMF & 28 & Decrease & 7 \\
NMFa & 28 & Decrease & 8 \\
2012 & 28 & Maintenance & 10 \\
AFT024 & 28 & Maintenance & 10 \\
AFT024 & 42 & Maintenance & 11 \\
\hline
\end{tabular}

aNormal marrow-derived feeder layer.

that the improved stem cell maintenance obtained with some of these cells may be associated with their expression of notch ligands ${ }^{14,15}$ or cytokines that signal through gp130, like LIF. ${ }^{16}$

With the cloning of the first cytokines known to be expressed by stromal cells, their potential to stimulate CRU amplification in vitro in the absence of stroma was explored. As summarized in Table 2, incubation of murine stem cell-containing suspensions in media supplemented with serum and Steel factor (SF, also known as stem cell factor or c-kit-ligand) plus one or more of IL-6, IL-11, Flt3-ligand (FL), or thrombopoietin (TPO) ${ }^{17-19}$ has usually been found to result in a slight reduction of the CRU population within the first 4 to 7 days, although in one report evidence of murine stem cell expansion after 6 days in culture with SF plus IL-11 was inferred from serial transplant experiments. ${ }^{20}$ In contrast, the use of serum-free media plus a combination of SF and IL-11 with ${ }^{21}$ or without $\mathrm{FL}^{18}$ has, for the first time, allowed modest net increases in murine CRU to be obtained in vitro. Similarly, when $\mathrm{CD} 34^{+} \mathrm{CD} 38^{-}$cells isolated from human cord blood have been cultured in serum-free media supplemented with SF, FL, IL-3, IL-6, G-CSF, small but significant increases in the number of human cells able to regenerate lymphoid and myeloid cells in irradiated immunodeficient mice were demonstrable. ${ }^{22,23}$ In 4 day cultures with murine cells, inclusion of anti-TGF- $\beta$ was also found to improve CRU maintenance and allow a $\sim 4$-fold increase in repopulating cells to be achieved. ${ }^{24}$

Interestingly, inclusion of even low concentrations of either IL-1 or IL-3 was found to abrogate the repopulating cell expansions that would otherwise have occurred in the cultures of murine cells. ${ }^{25}$ Negative effects of IL-3 on the in vitro expansion of human long-term culture-initiating cells (LTC- 


\begin{tabular}{|c|c|c|c|c|c|}
\hline Serum & Source of stem cells & Cytokines present & Days of culture & Effect on stem cell numbers (relative to input) & Ref. \\
\hline $15 \%$ & Mouse & SF/IL-3/IL-6/TGF- $\beta$ & 4 & Decrease & 24 \\
\hline $15 \%$ & Mouse & SF/IL-3/IL-6/anti-TGF- $\beta$ & 4 & Increase & 24 \\
\hline None & Human & SF/FL/IL-3/IL-6/G-CSF & 4 & Increase & 23 \\
\hline None & Mouse & SF/FL/IL-11 & 5 & Increase & 21 \\
\hline None & Human & SF/FL/IL-3/IL-6/G-CSF & $5-8$ & Increase & 22 \\
\hline $30 \%$ & Mouse & SF/IL-6 & 7 & Decrease & 35 \\
\hline $20 \%$ & Mouse & TPO & 7 & Decrease & 19 \\
\hline $20 \%$ & Mouse & FL/TPO or FL/IL-6 & 7 & Decrease & 19 \\
\hline None & Mouse & SF/FL/IL-11/TPO & 10 & Maintenance & 21 \\
\hline None & Mouse & SF/FL/IL-11 & 10 & Increase & 21 \\
\hline $20 \%$ & Mouse & FL/IL-11 & 14 & Increase & 18 \\
\hline $20 \%$ & Mouse & SF/IL-11 & 14 & Increase & 18 \\
\hline
\end{tabular}

IC), a population that is very closely related to $C R U,{ }^{22}$ has also been demonstrated. ${ }^{26}$ However, the relative concentrations of IL-3 that elicit this type of negative effect on human stem cell self-renewal appear to be higher than the concentrations of IL-3 that have a similar effect on murine stem cells.

Given the minimal expansions of stem cell numbers seen to date, the question as to whether the repopulating cells detected in cultured populations are the result of cell division (self-renewal events) has remained controversial. To investigate this question, we and others have begun to look specifically into the cell division kinetics of repopulating cells stimulated in vitro with various cytokines. Cell divisions can be tracked by time course studies of cells labeled with fluorescent dyes such as $\mathrm{PKH}-2,{ }^{27} \mathrm{PKH}-26,{ }^{27-29} \mathrm{PKH}-67^{13}$ and 5- (and 6-) carboxyfluorescein diacetate succinimidyl ester (CFSE). ${ }^{30,31}$ All of these markers confer a measurable and relatively stable level of fluorescence on the cells initially labeled. Their subsequent proliferation activity can then be inferred from the detection of a decreased level of fluorescence. Conversely, their failure to divide (without loss of viability) is indicated by the maintenance of a highly fluorescent phenotype.

In one such study, mouse bone marrow cells were labeled with $\mathrm{PKH}-2$ and then cultured for 7 days in the presence of SF, IL-3 and IL-6, at the end of which the majority of the repopulating cells still detectable were found to be contained within a population of cells whose fluorescence could not be distinguished from the starting population. This was interpreted as evidence that the initial stem cells had remained quiescent over this entire period. ${ }^{27}$ Similar results were obtained when more stringently sorted lin ${ }^{-} \mathrm{Sca}-1^{+} \mathrm{C}-\mathrm{kit}^{+}$cells were cultured with either TPO or FL/II-6. ${ }^{19}$ On the other hand, the vast majority of human $\operatorname{lin}^{-} \mathrm{CD} 34^{+}$Thy $-1^{+}$bone marrow cells stained with PKH-26 and cultured in TPO plus SF and $\mathrm{FL}^{29}$ could be shown to have divided within 6 days. Although this was not accompanied by a net expansion of cells with in vivo repopulating activity, all such cells were in the fraction of cells that had divided $\left(\mathrm{PKH}-26^{\mathrm{lo}}\right)$. The latter result suggests that some stem cell self-renewal divisions can take place in cultures lacking stromal cells, even though these do not occur at a frequency sufficient to counteract a concomitant loss of stem cell activity (due to their differentiation and/or death).

Both PKH-2 and PKH-26 have thus been powerful tools to document kinetic changes in vitro in populations of primitive hematopoietic cells. Nevertheless, the heterogeneity in staining intensity obtained with either of these dyes does not allow small differences in the numbers of divisions executed to be resolved. For example, in some of the studies just described, the possibility that one or two stem cell self-renewal divisions had occurred could not be excluded because of the breadth of the gate used to sort the $\mathrm{PKH}-2^{\text {bright },}, 27$ or $\mathrm{PKH}-26^{\text {high } 19,29}$ or $\mathrm{PKH}-67^{\text {high } 13}$ cells which spanned several (sometimes up to nine) division equivalents. The high resolution tracking possible with CFSE-labeling ${ }^{31}$ obviates these problems and may thus be better suited to such studies.

CFSE was first used to track the homing of lymphocytes ${ }^{32}$ and hepatocytes. ${ }^{33}$ After cells are exposed to CFSE, the intensity of cellular fluorescence decreases rapidly in the first $15 h, 31,32$ but then stabilizes. This allows cells to be reliably followed for at least 8 weeks ${ }^{32}$ unless they proliferate, which causes their fluorescence to be reduced with each cell division. In contrast to the PKH dyes mentioned, for CFSE it has been formally demonstrated by cell cycle experiments that the fluorescence of labeled cells is exactly halved at each successive mitosis. ${ }^{34}$ CFSE labeling could thus be used to establish the B cell differentiation events that occur in sequential cell generations. ${ }^{30}$ The improvement of the division tracking method implemented by Nordon et $a^{\beta 1}$ underscores the prediction of Hodgkin et $a^{\beta 0}$ that CFSE 'potentially allows the generation of comprehensive differentiation maps for stem cells undergoing development in vitro and in vivo.'

We have recently used CFSE labeling to show that the majority of lineage marker-negative $\left(\mathrm{lin}^{-}\right)$mouse bone marrow cells cultured in serum-free medium supplemented with FL, SF and IL-11 will undergo up to five divisions within 3 days and up to seven divisions within 4 days. In addition we found that the rate at which these cells proliferate in vivo (post-transplant) is similar (manuscript in preparation). Interestingly, when the proliferative history of the repopulating cells (CRU) in the cultures was examined, the majority of these still detectable after 3 days were in the fraction that had not yet divided whereas, 1 day later, CRU were detected exclusively in the fraction of cells that had divided. These studies provide independent confirmation by cell division tracking that totipotent hematopoietic stem cells defined by the most rigorous quantitative assay available will proliferate in vitro in defined media in response to FL, SF and IL-11 stimulation. Since this cytokine combination can also produce a net increase in CRU numbers, ${ }^{21}$ it would appear that this increase must be largely due to CRU cell division (self-renewal) events. This system now offers interesting opportunities to explore the intracellular signaling steps that are necessary for this response to be achieved.

\section{Acknowledgements}

The unpublished work reviewed here was supported by grants from the National Cancer Institute of Canada ( $\mathrm{NCIC}$ ) (with 
funds from the Terry Fox Run), Novartis and the NHLBI of the $\mathrm{NIH}$ (POI-55435). Presentation of some of this work at the 27th annual meeting of the International Society of Experimental Hematology was supported by a LEUKEMIA-funded New Investigator Award to R Oostendorp. J Audet holds a studentship from the Natural Sciences and Engineering Research Council of Canada and a scholarship from Science Council of British Columbia. C Eaves is a Terry Fox Cancer Research Scientist of the NCIC. The authors also thank B Fox for preparing the manuscript.

\section{References}

1 Szilvassy SJ, Humphries RK, Lansdorp PM, Eaves AC, Eaves CJ. Quantitative assay for totipotent reconstituting hematopoietic stem cells by a competitive repopulation strategy. Proc Natl Acad Sci USA 1990; 87: 8736-8740.

2 Dexter TM, Spooncer E, Toksoz D, Lajtha LG. The role of cells and their products in the regulation of in vitro stem cell proliferation and granulocyte development. J Supramol Struc 1980; 13: 513-524.

3 Ploemacher RE, Van Der Sluijs JP, Voerman JSA, Brons NHC. An in vitro limiting-dilution assay of long-term repopulating hematopoietic stem cells in the mouse. Blood 1989; 74: 2755-2763.

4 Sutherland HJ, Lansdorp PM, Henkelman DH, Eaves AC, Eaves C). Functional characterization of individual human hematopoietic stem cells cultured at limiting dilution on supportive marrow stromal layers. Proc Natl Acad Sci USA 1990; 87: 3584-3588.

5 Fraser CC, Szilvassy SJ, Eaves CJ, Humphries RK. Proliferation of totipotent hematopoietic stem cells in vitro with retention of longterm competitive in vivo reconstituting ability. Proc Natl Acad Sci USA 1992; 89: 1968-1972.

6 Van Der Sluijs JP, van den Bos C, Baert MRM, van Beurden CAJ, Ploemacher RE. Loss of long-term repopulating ability in long-term bone marrow culture. Leukemia 1993; 7: 725-732.

7 Lemieux ME, Eaves CJ. Identification of properties that can distinguish primitive populations of stromal cell-responsive lymphomyeloid cells from cells that are stromal cell-responsive but lymphoid-restricted and cells that have lympho-myeloid potential but are also capable of competitively repopulating myeloablated recipients. Blood 1996; 88: 1639-1648.

8 Gan OI, Murdoch B, Larochelle A, Dick JE. Differential maintenance of primitive human SCID-repopulating cells, clonogenic progenitors, and long-term culture-initiating cells after incubation on human bone marrow stromal cells. Blood 1997; 90: 641-650.

9 Ploemacher RE, Van Der Sluijs JP, van Beurden CAJ, Baert MRM, Chan PL. Use of limiting-dilution type long-term marrow cultures in frequency analysis of marrow-repopulating and spleen colony-forming hematopoietic stem cells in the mouse. Blood 1991; 78: 2527-2533.

10 Wineman J, Moore K, Lemischka I, Muller-Sieburg C. Functional heterogeneity of the hematopoietic microenvironment: rare stromal elements maintain long-term repopulating stem cells. Blood 1996; 87: 4082-4090.

11 Moore KA, Ema H, Lemischka IR. In vitro maintenance of highly purified, transplantable hematopoietic stem cells. Blood 1997; 89: 4337-4347.

12 Xu M-J, Tsuji K, Ueda T, Mukouyama Y-S, Hara T, Yang F-C, Ebihara $\mathrm{Y}$, Matsuoka S, Manabe A, Kikuchi A, Ito M, Miyajima A, Nakahata T. Stimulation of mouse and human primitive hematopoiesis by murine embryonic aorta-gonad-mesonephros-derived stromal cell lines. Blood 1998; 92: 2032-2040.

13 Ohneda O, Fennie C, Zheng Z, Donahue C, La H, Villacorta R, Cairns B, Lasky LA. Hematopoietic stem cell maintenance and differentiation are supported by embryonic aorta-gonad-mesonephros region-derived endothelium. Blood 1998; 92: 908-919.

14 Moore KA, Pytowski B, Witte L, Hicklin D, Lemischka IR. Hematopoietic activity of a stromal cell transmembrane protein containing epidermal growth factor-like repeat motifs. Proc Natl Acad Sci USA 1997; 94: 4011-4016.

15 Jones P, May G, Healy L, Brown J, Hoyne G, Delassus S, Enver T. Stromal expression of Jagged 1 promotes colony formation by fetal hematopoietic progenitor cells. Blood 1998; 92: 1505-1511.

16 Szilvassy SJ, Weller KP, Lin W, Shrama AK, Ho ASY, Tsukamoto
Editorial

RAJ Oostendorp et al

A, Hoffman R, Leiby KR, Gearing DP. Leukemia inhibitory factor upregulates cytokine expression by a murine stromal cell line enabling the maintenance of highly enriched competitive repopulating stem cells. Blood 1996; 87: 4618-4628.

17 Rebel VI, Dragowska W, Eaves CJ, Humphries RK, Lansdorp PM. Amplification of Sca- $1^{+}$Lin $^{-} \mathrm{WGA}^{+}$cells in serum-free cultures containing Steel factor, interleukin-6, and erythropoietin with maintenance of cells with long-term in vivo reconstituting potential. Blood 1994; 83: 128-136.

18 Yonemura Y, Ku H, Lyman SD, Ogawa M. In vitro expansion of hematopoietic progenitors and maintenance of stem cells: comparison between Flt3/Flk-2 ligand and kit ligand. Blood 1997; 89: 1915-1921.

19 Matsunaga T, Kato T, Miyazaki H, Ogawa M. Thrombopoietin promotes the survival of murine hematopoietic long-term reconstituting cells: comparison with the effects of FLT3/FLK-2 ligand and interleukin-6. Blood 1998; 92: 452-461.

20 Holyoake TL, Freshney MG, McNair L, Parker AN, McKay PJ, Steward WP, Fitzsimons E, Graham GJ, Pragnell IB. Ex vivo expansion with stem cell factor and interleukin-11 augments both shortterm recovery posttransplant and the ability to serially transplant marrow. Blood 1996; 87: 4589-4595.

21 Miller CL, Eaves CJ. Expansion in vitro of adult murine hematopoietic stem cells with transplantable lympho-myeloid reconstituting ability. Proc Natl Acad Sci USA 1997; 94: 13648-13653.

22 Conneally E, Cashman J, Petzer A, Eaves C. Expansion in vitro of transplantable human cord blood stem cells demonstrated using a quantitative assay of their lymphomyeloid repopulating activity in nonobese diabetic-scid/scid mice. Proc Natl Acad Sci USA 1997; 94: 9836-9841.

23 Bhatia M, Bonnet D, Kapp U, Wang JCY, Murdoch B, Dick JE. Quantitative analysis reveals expansion of human hematopoietic repopulating cells after short-term ex vivo culture. J Exp Med 1997; 186: 619-624.

24 Soma T, Yu JM, Dunbar CE. Maintenance of murine long-term repopulating stem cells in ex vivo culture is affected by modulation of transforming growth factor- $\beta$ but not macrophage inflammatory protein-1 $\alpha$ activities. Blood 1996; 87: 4561-4567.

25 Yonemura Y, Ku H, Hirayama F, Souza LM, Ogawa M. Interleukin 3 or interleukin 1 abrogates the reconstituting ability of hematopoietic stem cells. Proc Natl Acad Sci USA 1996; 93: 4040-4044.

26 Zandstra PW, Conneally E, Petzer AL, Piret JM, Eaves CJ. Cytokine manipulation of primitive human hematopoietic cell self-renewal. Proc Natl Acad Sci USA 1997; 94: 4698-4703.

27 Traycoff CM, Cornetta K, Yoder MC, Davidson A, Srour EF. Ex vivo expansion of murine hematopoietic progenitor cells generates classes of expanded cells possessing different levels of bone marrow repopulating potential. Exp Hematol 1996; 24: 299-306.

28 Lansdorp PM, Dragowska W, Mayani H. Ontogeny-related changes in proliferative potential of human hematopoietic cells. J Exp Med 1993; 178: 787-791.

29 Luens KM, Travis MA, Chen BP, Hill BL, Scollay R, Murray LJ. Thrombopoietin, kit ligand, and flk2/flt3 ligand together induce increased numbers of primitive hematopoietic progenitors from human CD34+Thy-1+ Lin $^{-}$cells with preserved ability to engraft SCID-hu bone. Blood 1998; 91: 1206-1215.

30 Hodgkin PD, Lee J-H, Lyons AB. B cell differentiation and isotype switching is related to division cycle number. J Exp Med 1996; 184: $277-281$.

31 Nordon RE, Ginsberg SS, Eaves CJ. High resolution cell division tracking demonstrates the Flt3-ligand-dependence of human marrow $\mathrm{CD}^{4}{ }^{+} \mathrm{CD}^{-} 8^{-}$cell production in vitro. $\mathrm{Br} /$ Haematol 1997; 98: 528-539.

32 Weston SA, Parish CR. New fluorescent dyes for lymphocyte migration studies. Analysis by flow cytometry and fluorescence nicroscopy. J Immunol Meth 1990; 133: 87-97.

33 Fujioka H, Hunt PJ, Rozga J, Wu G-D, Cramer DV, Demetriou AA, Moscioni AD. Carboxyfluorescein (CFSE) labelling of hepatocytes for short-term localization following intraportal transplantation. Cell Transplant 1994; 3: 397-408.

34 Lyons AB, Parish CR. Determination of lymphocyte division by flow cytometry. J Immunol Meth 1994; 171: 131-137.

35 Rebel VI, Lansdorp PM. Culture of purified stem cells from fetal liver results in loss of in vivo repopulating potential. J Hematother 1996; 5: 25-37. 
